\title{
Microbial food web structural and functional responses to oyster and fish as top predators
}

\author{
Behzad Mostajir ${ }^{1, *}$, Cécile Roques ${ }^{1}$, Corinne Bouvier ${ }^{1}$, Thierry Bouvier ${ }^{1}$, \\ Éric Fouilland ${ }^{1}$, Patrice Got ${ }^{1}$, Emilie Le Floc' ${ }^{1}{ }^{1}$, Jean Nouguier ${ }^{1}$, Sébastien Mas ${ }^{2}$, \\ Richard Sempéré ${ }^{3}$, Télesphore Sime-Ngando ${ }^{4}$, Marc Troussellier ${ }^{1}$, Francesca Vidussi ${ }^{1}$ \\ ${ }^{1}$ Center of Marine Biodiversity, Exploitation and Conservation, UMR 9190, CNRS/Université de Montpellier/IRD/IFREMER, \\ Place Eugène Bataillon, Université de Montpellier, Case 93, 34095 Montpellier Cedex 05, France \\ ${ }^{2}$ Observatoire de Recherche Méditerranéen de l'Environnement, UMS 3282, \\ Centre d'Ecologie Marine Expérimentale MEDIMEER, Station Méditerranéenne de l'Environnement Littoral, Université de \\ Montpellier/CNRS/IRD, Place Eugène Bataillon, Université de Montpellier, Case 60, 34095 Montpellier Cedex 05, France \\ ${ }^{3}$ Aix-Marseille Université, Mediterranean Institute of Oceanography (UMR 7294), CNRS/IRD, Aix Marseille University, \\ Toulon University, Case 901, Campus de Luminy, Bâtiment Méditerranée, 13288 Marseille Cedex 9, France \\ ${ }^{4}$ Laboratoire Microorganismes: Génome et Environnement (UMR CNRS 6023), Clermont Université Blaise Pascal, \\ Complexe Scientifique des Cézeaux, 24 Avenue des Landais, BP 80026, 63171 Aubière Cedex, France
}

\begin{abstract}
The impact of fish and oysters on components of the pelagic microbial food web (MFW) was studied in a $10 \mathrm{~d}$ mesocosm experiment using Mediterranean coastal waters. Two mesocosms contained natural water only ('Controls'), 2 contained natural water with Crassostrea gigas ('Oyster'), and 2 contained natural water with Atherina spp. ('Fish'). Abundances and biomasses of microorganisms (viruses, bacteria, phytoplankton, heterotrophic flagellates, and ciliates) were measured to estimate their contribution to the total microbial carbon biomass. Two MFW indices, the microbial autotroph:heterotroph $\mathrm{C}$ biomass ratio $(\mathrm{A}: \mathrm{H})$ structural index and the gross primary production:respiration ratio (GPP:R) functional index, were defined. In the Fish mesocosms, selective predation on zooplankton led to a trophic cascade with $51 \%$ higher phytoplankton $\mathrm{C}$ biomass and consequently higher A:H and GPP:R than in the Controls. By the end of the experiment, the Oyster mesocosms had a bacterial C biomass $87 \%$ higher and phytoplankton C biomass $93 \%$ lower than the Controls, giving significantly lower A:H and GPP:R $(<1)$. Overall, the results showed that wild zooplanktivorous fish had a cascading trophic effect, making the MFW more autotrophic (both indices $>1$ ), whereas oyster activities made the MFW more heterotrophic (both indices $<1$ ). These MFW indices can therefore be used to assess the impact of multiple local and global forcing factors on the MFW. The results presented here also have implications for sustainable management of coastal environments, suggesting that intense cultivation of filter feeders can be coupled with management to encourage wild local zooplanktivorous fishes to maintain a more resilient system and preserve the equilibrium of the MFW.
\end{abstract}

KEY WORDS: Microbial food web - Virioplankton - Bacterioplankton - Phytoplankton · Protozooplankton $\cdot$ Crassostrea $\cdot$ Atherina $\cdot$ Autotrophy $\cdot$ Heterotrophy

Resale or republication not permitted without written consent of the publisher

\section{INTRODUCTION}

Marine ecosystems, in particular phototrophic components of the pelagic microbial food web (MFW), fix nearly half of the total global carbon
(Field et al. 1998) and have a major effect on global climate, particularly in the context of climate change and increasing atmospheric $\mathrm{CO}_{2}$ with its consequences such as global warming and ocean acidification. There are continuous interactions among 
microorganisms within the MFW (heterotrophic bacteria, flagellates, ciliates, phytoplankton, and viruses) and between the MFW and multicellular organisms at higher trophic levels (Mostajir et al. 2015). The strength of these interactions in the pelagic MFW can be modified by natural and anthropogenic chemical, physical, and biological forcing factors, leading to changes in MFW structure and functioning. There have been numerous investigations on the effects of chemical and physical forcing factors such as acidification (Riebesell et al. 2013), water warming (Vidussi et al. 2011, Fouilland et al. 2013, von Scheibner et al. 2014), nutrient loading by flood events (Pecqueur et al. 2011), and ultravioletB radiation (Mostajir et al. 1999, Vidussi et al. 2011) on specific components of the MFW, or on the MFW in general. However, few studies, particularly in seawater, have focused on the responses of the MFW to top-down alterations. For instance, most studies of the effects of mariculture (shellfish and fish farms) in coastal zones have focused on the feeding regimes of cultured bivalves or fish to determine the organisms that contribute to their diet. Most studies found that bivalves, especially oysters, exerted top-down control on phytoplankton (Newell et al. 2007), but some showed that oysters grazed mainly on non-chlorophyllous particles (Charpy et al. 2012) or heterotrophic microorganisms (Dupuy et al. 2000). It has been established that fish predation can control the plankton community efficiently, and this biotic top-down control has been used since the 1980 s to regulate primary production in lakes (Carpenter et al. 1987).

However, few studies have considered the effects of mariculture (shellfish and fish farms) on the structure and functioning of the MFW as a whole in an integrated way. Cultivated oysters are important anthropogenic biological forcing factors in coastal waters and, like fish, can be considered top predators of MFW components. The 2 animals selected for this experiment have different feeding strategies: the oyster Crassostrea gigas is a non-selective filter feeder cultivated in many farms in various coastal waters, and local wild sand smelt (Atherina spp.) is a selective zooplanktivore which is widespread in the Mediterranean and other adjacent seas as well as in Mediterranean lagoons. This study set out to determine (1) how oysters and fish as top predators change the abundance and biomass of all communities in the MFW, (2) whether these changes influence the structure of the MFW, and (3) whether there are simultaneous changes in the structure and functioning of the MFW.

\section{MATERIALS AND METHODS}

\section{Experimental site}

The mesocosm experiment was carried out at the Mediterranean center for Marine Ecosystem Experimental Research (MEDIMEER) (www.medimeer. univ-montp2.fr/) based at the marine station of Sète

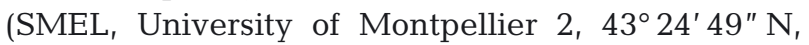
$\left.3^{\circ} 41^{\prime} 19^{\prime \prime} \mathrm{E}\right)$.

The mesocosms were immersed in the Thau lagoon on the French Mediterranean coast. Intensive shellfish farms (oysters and mussels) cover about one-fifth of the lagoon area, and the lagoon provides $10 \%$ of French oyster production (Souchu et al. 1998). The Thau watershed covers an area of $280 \mathrm{~km}^{2}$. Thau is not a deep lagoon (maximum depth $10 \mathrm{~m}$, average depth $4.5 \mathrm{~m}$ ), and there are large variations in salinity (between 24 and 38) and water temperature (from 4 to $27^{\circ} \mathrm{C}$ ). Concentrations of nutrients in the Thau lagoon are relatively low (nitrate concentrations $<1 \mu \mathrm{M})$, although they can increase after flood events.

\section{Experimental design and mesocosms}

Six mesocosms (maximum water depth of $2 \mathrm{~m}$ ) were moored near the MEDIMEER pontoon on 26 October 2005 (Day 0). Natural lagoon surface water was filtered through a $1000 \mu \mathrm{m}$ mesh sieve and after pooling was used to simultaneously fill all mesocosms to a final volume of $2260 \mathrm{l}$ for each mesocosm. Note that these pelagic mesocosms mimic only the natural water column without including the sediment. Two of the mesocosms contained natural water ('Control'), 2 contained natural water with 10 Crassostrea gigas ('Oyster'), and 2 contained natural water with 29 Atherina ('Fish'). The water column in each mesocosm was continuously mixed by a pump (Iwaki MD30MX) to ensure that the conditions were uniform and to avoid particle settling. The mesocosms were not refilled after each sampling, and the flow rate of the pumps used for mixing the water column of the mesocosms was adjusted using an ultrasonic flowmeter (Minisonic P, Ultraflux) to ensure a turnover of the whole water mass within the mesocosm every $1 \mathrm{~h}$, taking into account the reduction of total volume due to daily sampling. Detailed information about the mesocosms can be found in Nouguier et al. (2007). 


\section{Capture of oysters and fish and acclimation}

Oysters were collected by divers in the Thau lagoon on 17 October 2005 and kept in an 801 container continuously supplied with lagoon water. Before the oysters were introduced into the mesocosms, they were brushed to eliminate any organisms adhering to their valves. From 26 to 27 October, they were acclimated in $0.2 \mu \mathrm{m}$ filtered lagoon water (Whatman, 0.8 and $0.2 \mu \mathrm{m}$ ) and oxygenized continuously by bubbling. To check that the oysters were alive throughout the experiment, the frequency of valve opening during the experiment was continuously monitored. To do this, 2 PVC shelves were constructed, each with 2 rows of 5 plates, and 10 oysters were fixed to each shelf. One shelf was placed in each of the 2 Oyster mesocosms in the afternoon on 27 October 2005 (Day 1). At the same time, dummy shelves of the same material and structure but without oysters were placed in the other 4 mesocosms (Control and Fish mesocosms) to provide the same amount of shade as in the Oyster mesocosms. Each shelf (Fig. 1A) was fitted with a measurement system consisting of an arm attached to the top shell of each oyster to amplify the valve movement, with a Hall effect sensor on the shelf and a magnet on the arm (Mostajir et al. 2012). The output voltage from the sensor, which depended on the gape, was recorded every $2 \mathrm{~s}$ by a data logger (CR23X, Campbell Scientific). The data were averaged and saved every $5 \mathrm{~min}$. Monitoring the oyster gape confirmed that all 20 oysters remained alive during the experiment. As an example, the gape measurement of one of the oysters during the experiment is illustrated in Fig. 1B, which shows that it was open continuously at the beginning of the experiment, indicating continuous feeding. Towards the end of the experiment, oyster filtering became irregular, with periods when the oyster was closed.

Pelagic fish (sand smelt, $\mathrm{n}=200$ ) were caught using a fish net on 3 October 2005 in several different localities in the Thau lagoon and adjacent basins and kept in an $80 \mathrm{l}$ container continuously supplied with lagoon water. From 26 to 27 October, the fish were acclimated in $0.2 \mu \mathrm{m}$ filtered lagoon water (PALL filter, 0.8 and $0.2 \mu \mathrm{m}$ ) and oxygenized continuously by bubbling. Fish $(n=29)$ were placed in each of 2 mesocosms on 27 October 2005 (Day 1; Fish mesocosms). The fish were caught at the end of the experiment, and 28 fish in each of the duplicate mesocosms were found still alive.
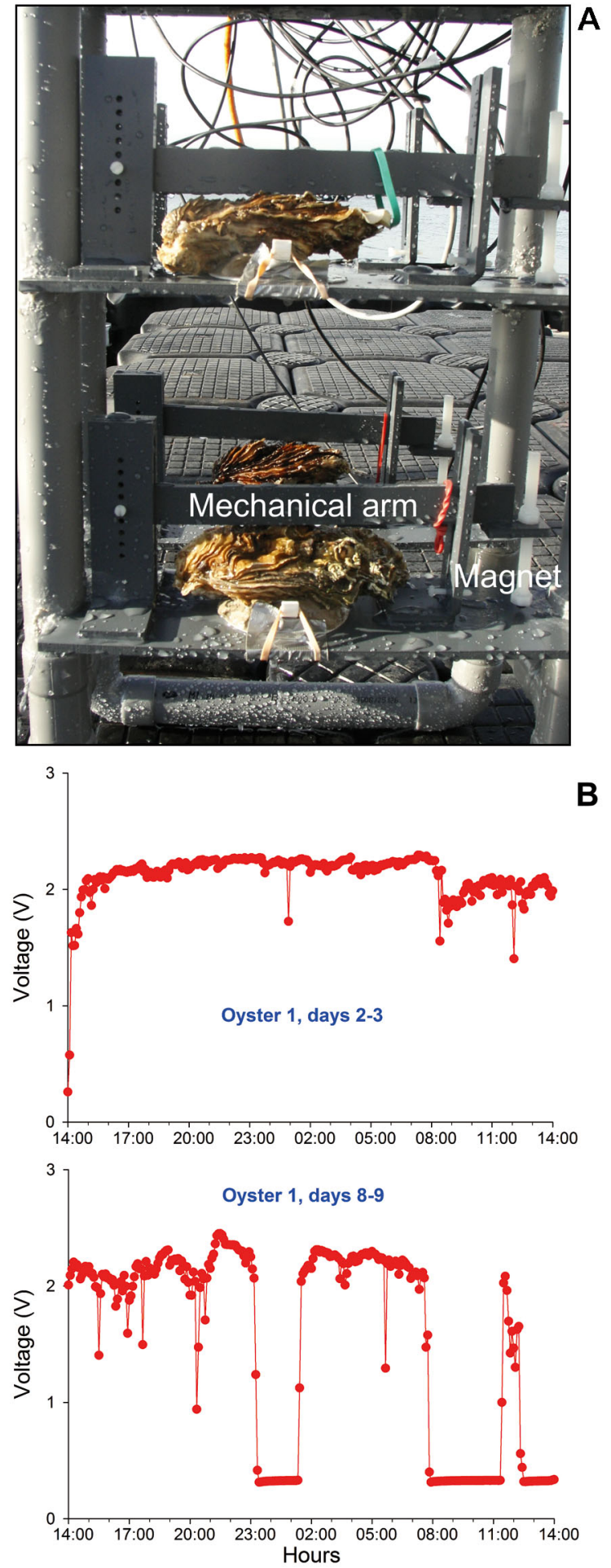

Fig. 1. (A) Shelf with 2 rows of 5 plates for simultaneously monitoring the gapes of 10 oysters Crassostrea gigas during the experiment using a measurement system consisting of an arm, a magnet, and a sensor. (B) Data on the gape of one of the oysters, averaged and stored every $5 \mathrm{~min}$, showing the gape on most of Days 2 and 3 and the period when the oyster was sometimes closed at the end of the experiment (Days 8 and 9) 


\section{Light, temperature, and salinity}

Incident PAR was monitored every $10 \mathrm{~min}$ between 14:00 h on Day 1 (27 October) and 23:50 h on Day 8 (3 November) using a spectroradiometer (TriOS RAMSES ACC hyperspectral) connected to a Campbell Scientific data logger (CR23X), as described by Nouguier et al. (2007). The water temperature in each mesocosm was measured every 5 min by Campbell Scientific 107 temperature probes situated at 3 depths in the mesocosms $(0.4,0.8$, and $1.2 \mathrm{~m})$. For each probe, the data were averaged and recorded every $10 \mathrm{~min}$. The salinity in all mesocosms was measured every day between 10:00 and 11:00 h using a WTW 197i conductivity meter.

\section{Mesocosm sampling}

When all mesocosms had been filled and the water column in each mesocosm had been mixed for $1 \mathrm{~h}$ using the pump in each mesocosm, a 201 sample was taken using a pump (Iwaki MD30MX) from one of the control mesocosms to characterize the initial water conditions on Day 0. Samples were taken once a day at 10:00 $\mathrm{h}$ from Day 1 until the end of the experiment (Day 9) to measure nutrients and dissolved organic carbon as well as the abundances of viruslike particles (VLPs), heterotrophic bacteria, and chlorophyll concentrations.

Samples were taken from all mesocosms on Days 1, $3,5,7$, and 9 between 10:00 and 11:00 h to measure the net oxygen production rates, plankton community respiration, and abundances of heterotrophic flagellates, ciliates (samples were also taken on Day 2), and larger zooplankton (samples were not taken on Day 5). The gross oxygen production was estimated from net community production and respiration.

\section{Nutrients}

Samples for nitrite and nitrate $\left(\mathrm{NO}_{2}{ }^{-}+\mathrm{NO}_{3}{ }^{-}\right)$, phosphate $\left(\mathrm{PO}_{4}{ }^{3-}\right)$, and silicate $\left(\mathrm{SiO}_{4}{ }^{4-}\right)$ analysis were collected in acid-washed polyethylene bottles. Samples were vacuum filtered $(<20 \mathrm{kPa})$ onto precombusted $\mathrm{GF} / \mathrm{F}$ filters using pre-rinsed polycarbonate filter holders (Nalgene). Filtered sub-samples for $\mathrm{NO}_{2}{ }^{-}+\mathrm{NO}_{3}{ }^{-}$ and $\mathrm{PO}_{4}{ }^{3-}$ analysis were stored frozen $\left(-20^{\circ} \mathrm{C}\right)$ in $125 \mathrm{ml}$ borosilicate bottles. Filtered sub-samples for $\mathrm{SiO}_{4}{ }^{4-}$ analysis were stored at $4^{\circ} \mathrm{C}$ in $125 \mathrm{ml}$ polyethylene bottles. Samples for dissolved nutrients were subsequently analyzed using a standard automated colorimetric method (Wood et al. 1967, Tréguer \& Le Corre 1975) on a segmented flow Bran Luebbe autoanalyzer II. $\mathrm{NH}_{4}$ concentration was not included in the dissolved nitrogen $\left(\mathrm{NO}_{3}+\mathrm{NO}_{2}\right)$ concentrations due to methodological problems.

\section{Dissolved organic carbon (DOC)}

To measure DOC, mesocosm samples collected in glass bottles were filtered through GF/F filters into $10 \mathrm{ml}$ Pyrex tubes (all materials were pre-combusted at $450^{\circ} \mathrm{C}$ for $6 \mathrm{~h}$ ), immediately acidified with $85 \%$ $\mathrm{H}_{3} \mathrm{PO}_{4}$ (final $\mathrm{pH} \sim 2$ ), and stored at $4^{\circ} \mathrm{C}$ in the dark. The DOC concentration was measured using a Shimadzu TOC-5000 total carbon analyzer with $1.2 \%$ platinum-coated silica pillows as a catalyst (Sohrin \& Sempéré 2005). The DOC concentration calculation was obtained from peak areas and a 4-point calibration curve obtained daily by injecting working solutions of acidified (with $\mathrm{H}_{3} \mathrm{PO}_{4}$ ) potassium hydrogen phthalate that were freshly prepared every $3 \mathrm{~d}$ by diluting the stock solution with Milli-Q water. The running blank was subtracted from the average peak area of the samples ( $n=3$ or 4$)$ divided by the slope of the calibration curve. The running blank was determined as the average of all peak areas of the MilliQ water acidified with $\mathrm{H}_{3} \mathrm{PO}_{4}$. The acidified Milli-Q water was injected in triplicate every 4 samples. To ensure the accuracy and the stability of the DOC analysis, low-carbon water and deep seawater reference distributed by the laboratory of D. Hansell (University of Miami, USA) were measured daily.

\section{Net oxygen production, dark oxygen respiration, and gross oxygen production}

To measure the oxygen production and respiration, 12 borosilicate bottles $(120 \mathrm{ml}$ each) were carefully filled from each 201 sampling carboy using a silicone rubber tube. Four bottles were immediately fixed (time 0) using reagents prepared as described by Caritt \& Carpenter (1966). In order to measure the net oxygen production (net community production: $\mathrm{NCP}), 4$ other bottles were wrapped in a piece of the plastic sheet used for constructing the mesocosms and incubated in surface waters of the Thau Lagoon (0.5 m depth) close to the mesocosms from 10:00 to $\sim 18: 00 \mathrm{~h}$ (local time). In order to measure the dark oxygen respiration (respiration: R), 4 darkened borosilicate bottles were incubated for $24 \mathrm{~h}$ in surface waters. After incubation, all 8 bottles were then fixed 
as described above. The dissolved oxygen concentrations were determined using automatic Winkler titration with potentiometric end-point detection (Crisson). The NCP and R were then calculated. The gross oxygen production (gross primary production: GPP) was estimated from NCP and R. All parameters were expressed in hourly rates $\left(\mu \mathrm{g} \mathrm{O} \mathrm{O}_{2} \mathrm{l}^{-1} \mathrm{~h}^{-1}\right)$, as light, temperature, and microbial biomass were low in Thau Lagoon in this period. To obtain a good estimate of the hourly rates of GPP during the daylight period, measurements of NCP were performed during the shortest period possible where the light was at the highest level (between 10:00 and 18:00 h). Hourly respiration rates were assessed in darkness using $24 \mathrm{~h}$ incubations, which allowed us to observe a significant decrease in $\mathrm{O}_{2}$ concentration. Respiration activity was assumed to be similar during the entire incubation period.

\section{Viruses, microorganisms, and metazooplankton}

For the enumeration of VLPs, $1.8 \mathrm{ml}$ water samples were fixed with $0.02 \mu \mathrm{m}$ filtered buffered alkaline formalin (final concentration $2 \% \mathrm{v} / \mathrm{v}$, from a $37 \% \mathrm{w} / \mathrm{v}$ solution of commercial formaldehyde). In the laboratory, subsamples $(0.5$ to $1 \mathrm{ml}$ ) were vacuum filtered ( $<15 \mathrm{kPa}$ vacuum) through $0.02 \mu \mathrm{m}$ pore size Anodisc filters (Whatman) with $1.2 \mu \mathrm{m}$ pore size cellulose acetate backing filters. After staining with SYBR Green I dye (Molecular Probes Europe; final dilution: $2.5 \times 10^{-3}$ fold) (Noble \& Fuhrman 1998), the filters were air dried on absorbent paper and mounted between a slide and glass cover slip with $30 \mu \mathrm{l}$ of Citifluor antifadent mounting medium with about $20 \%$ (v/v) of Vecta Shield (Vector Laboratories). Vecta Shield was added to reduce the fading of the dye and give highly stable fluorescence. If the slides were not analyzed immediately, they were stored at $-80^{\circ} \mathrm{C}$ before enumeration under an epifluorescence microscope (Leica DC 300F) using a magnification of 1000x.

For the enumeration of heterotrophic bacteria, $1.6 \mathrm{ml}$ water samples were fixed with formalin ( $2 \%$ final concentration), frozen in liquid nitrogen $\left(-180^{\circ} \mathrm{C}\right)$, and kept at $-80^{\circ} \mathrm{C}$ until analysis. Aliquots of thawed samples $(300 \mu \mathrm{l})$ were stained with $8 \mu \mathrm{l}$ SYBR Green I (Molecular Probes) for $15 \mathrm{~min}$ at $4^{\circ} \mathrm{C}$ in the dark (Marie et al. 1997). After adding 0.96 and $2 \mu \mathrm{m}$ beads (PolySciences) and TruCount beads (with known concentration, lot 49912, BD Biosciences) as an internal standard, the bacteria were enumerated and analyzed using a FACSCalibur (Becton-Dickin- son) flow cytometer, fitted with a $488 \mathrm{~nm}, 15 \mathrm{~mW}$, laser, for 2 to $3 \mathrm{~min}$ at a low rate $\left(12-15 \mu \mathrm{l} \mathrm{min}{ }^{-1}\right)$ using the FL1 detector $(\lambda=530 \mathrm{~nm})$. All cytometric data were logged and analyzed using Cell Quest (Becton-Dickinson).

Heterotrophic flagellates (HFs) were enumerated in 3 size classes of $<3,3-5$, and $5-10 \mu \mathrm{m}$, as the larger HFs $>10 \mu \mathrm{m}$ were rare (only sporadically present), with a low density in the present study. Water samples $(10 \mu \mathrm{l})$ from each mesocosm were fixed with formalin ( $4 \%$ final concentration) and kept at $4{ }^{\circ} \mathrm{C}$ in the dark. Samples were stained with $0.8 \mathrm{ml}$ of DAPI $\left(4^{\prime}, 6^{\prime}\right.$-diamidino-2-phenyindole hydrochloride) and vacuum filtered $(<7 \mathrm{kPa})$ onto a $25 \mathrm{~mm}$ black Nuclepore polycarbonate membrane $(0.2 \mu \mathrm{m}$ pore size) The filter was placed on a slide and examined using an epifluorescence microscope (Olympus AX 70) with a $100 \times$ objective.

Ciliates were enumerated in 5 size classes (10-15, $15-20,20-25,25-30$, and 30-35 $\mu \mathrm{m}$ ) using an Olympus inverted microscope (IX-70) in $100 \mathrm{ml}$ water samples from each mesocosm that had been preserved with commercial Lugol's solution (6\% final concentration) and allowed to settle for $24 \mathrm{~h}$ in the dark. Larger ciliates $(>35 \mu \mathrm{m})$ were not included in the counts because they were present randomly in the samples.

For metazooplankton enumeration and analysis, $60 \mathrm{l}$ samples were taken from each mesocosm, using 201 polycarbonate containers $(n=3)$ and screened through a $60 \mu \mathrm{m}$ net screen, fixed with neutralized formalin ( $4 \%$ final concentration), and kept at $4^{\circ} \mathrm{C}$ in the dark. The metazooplankton were then enumerated by image-based analysis (Lam-Hoai 1991, LamHoai et al. 1997, 2006).

For phytoplankton pigment assays (chlorophyll a), samples (1-2 l) were vacuum filtered $(25 \mathrm{kPa})$ onto glass-fiber filters $(25 \mathrm{~mm}, 0.7 \mathrm{~mm}$ nominal pore size, Whatman GF/F), stored in liquid nitrogen, and kept at $-80^{\circ} \mathrm{C}$ until analysis. Pigments were extracted in $3 \mathrm{ml}$ of $95 \%$ methanol (Vidussi et al. 2011) and analyzed by high-performance liquid chromatography (HPLC) as described by Zapata et al. (2000) using a Waters HPLC system as described by Vidussi et al. (2011).

\section{Estimating carbon biomass partitioning in the MFW}

In order to estimate the $\mathrm{C}$ biomass distribution within MFW microorganisms for each of the mesocosms, the abundances of viruses and bacteria, the 
biovolume of HFs and ciliates, and the phytoplankton chlorophyll biomasses were converted to equivalent C biomass.

The VLP abundances were converted to $\mathrm{C}$ biomass using the factor $0.055 \mathrm{fg} \mathrm{C}$ virus $^{-1}$ (Steward et al. 2007). Total heterotrophic bacterial abundances were converted to $\mathrm{C}$ biomass using the factor $20 \mathrm{fg} \mathrm{C}$ bacterium $^{-1}$ (Sime-Ngando et al. 1995). To calculate the volume of HF, they were considered to be spherical with a diameter of $2 \mu \mathrm{m}$ for the size class of $<3 \mu \mathrm{m}$ (as most of them were around $2 \mu \mathrm{m}$ ), and 4 and 7.5 $\mu \mathrm{m}$ as the mean diameters of the size classes of 3-5 and $5-10 \mu \mathrm{m}$, respectively. The total $\mathrm{C}$ biomass of HFs $<10 \mu \mathrm{m}$ was calculated using the factor $0.22 \mathrm{pg}$ $\mathrm{C} \mu \mathrm{m}^{-3}$ (Booth 1993). The volumes of ciliates $<35 \mu \mathrm{m}$ were calculated for each of the size classes considering the ciliates to be spherical with mean diameter of $12.5,17.5,22.5,27.5$, and $32.5 \mu \mathrm{m}$, respectively, for each size class. The ciliate $\mathrm{C}$ biomass was estimated using the equation of Putt \& Stoecker (1989) using

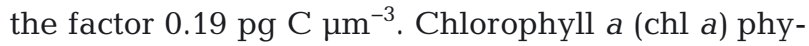
toplankon biomasses were converted to $\mathrm{C}$ biomass using a value of 57 (Latasa et al. 2005) as previously used in a mesocosm experiment in the Thau lagoon (Vidussi et al. 2011). The total microbial C biomass ( $\mu \mathrm{g} \mathrm{C}^{-1}$ ) was calculated as the sum of the $\mathrm{C}$ biomasses for all of these microorganisms.

\section{Statistical processing}

Some of the data sets for the Oyster, Fish, and Control mesocosms were $\log _{10}$ transformed and tested using the Shapiro-Wilk test for normality. Repeatedmeasure analyses of variance (RM-ANOVAs) were then performed for each variable using SYSTAT version 11 to test the differences between the Oyster mesocosms and the Controls and between the Fish mesocosms and the Controls. When the data were significantly different, a Bonferroni test was performed. Differences between the Oyster or Fish mesocosms and the Controls given below were considered significant at $\mathrm{p} \leq 0.05$ for the whole experiment and, where applicable, for each day of the experiment.

\section{RESULTS}

\section{Light and water temperature}

The photosynthetically available radiation (PAR: $400-700 \mathrm{~nm}$ ) was above $920 \mu \mathrm{mol}$ quanta $\mathrm{m}^{-2} \mathrm{~s}^{-1}$ on Days 6,7 , and 8 of the experiment. Water tempera- ture varied between 17.40 and $18.25^{\circ} \mathrm{C}$ during the experiment, with a mean of $17.96^{\circ} \mathrm{C}$, and salinity varied between 37.8 and 38.2 (data not shown), likely due to evaporation.

\section{Nitrates, phosphate, silicate, and DOC}

The initial mean nitrate concentration $\left(\mathrm{NO}_{2}+\mathrm{NO}_{3}\right.$, Fig. 2A) for all mesocosms was $0.21 \pm 0.04$ (SD) $\mu \mathrm{M}$, decreasing to $0.10 \pm 0.02$ and $0.11 \pm 0.04 \mu \mathrm{M}$ on Days 1 and 2 (Fig. 2A). After a minor increase on Day 5 (mean $0.12 \mu \mathrm{M}$ ), the nitrate concentration decreased slightly and remained more or less constant during the last $4 \mathrm{~d}$ of the experiment in the Controls. There were no significant differences between the Oyster or Fish mesocosms and the Controls despite some temporal variations in nitrate concentration during the experiment.

The phosphate concentration decreased slightly from about $0.20 \pm 0.03$ to $0.13 \pm 0.01 \mu \mathrm{M}$ from Day 0 to Day 7 in all mesocosms (Fig. 2B). There was no significant difference between the Oyster or Fish mesocosms and the Controls.

The silicate concentration decreased continuously from Day 0 to Day 4 in all mesocosms from $10.10 \pm$ 0.44 to a mean of $2.23,1.90$ and $1.89 \mu \mathrm{M}$ in the Oyster, Controls and Fish mesocosms, respectively (Fig. 2C). The large decrease in silicate concentration at the beginning of the experiment was related to the assimilation of diatoms, which were among the main components of the phytoplankton community in this experiment (notably colonies of Thalassionema nitzschioides; data not shown). From Day 4 until the end of the experiment, silicate concentrations remained more or less constant in both Control and Fish mesocosms, with slight decreases on Day 7, without being significant. Silicate concentrations were significantly different between the Oyster and Control mesocosms for the whole experiment, with significantly higher concentrations on Days 5, 7, and 9 in the Oyster mesocosms than in the Controls.

After decreasing slightly on Day 1, the DOC concentrations increased continuously up to a mean of $295.08 \mu \mathrm{M}$ in the Controls and a mean of $304.49 \mu \mathrm{M}$ in the Fish mesocosms (Fig. 2D) on Day 4, and then decreased and increased on Days 5, 6, and 7, before remaining more or less constant until Day 9. There were no significant differences in DOC concentration between the Oyster or Fish mesocosms and the Controls, even including the peak DOC concentration in the Oyster mesocosms on Day 3 (mean $335.52 \mu \mathrm{M})$. 

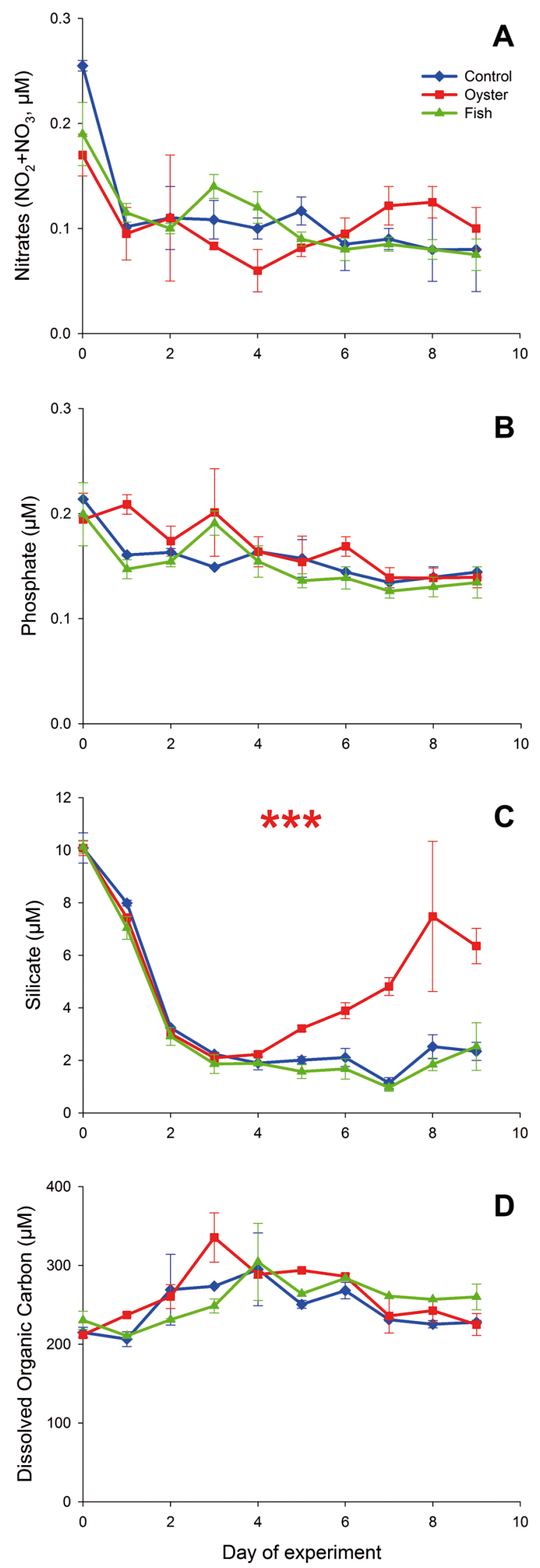

\section{Net oxygen production, dark oxygen respiration, and gross oxygen production}

The mean net oxygen production (NCP) for all mesocosms was $134.52 \pm 15.84 \mathrm{\mu g} \mathrm{l}^{-1} \mathrm{~h}^{-1}$ on Day 1 , decreasing to a mean of $-16.13,19.02$ and $11.17 \mu^{l^{-1}}$ $\mathrm{h}^{-1}$ in the Oyster, Fish and Controls mesocosms, respectively, at the end of the experiment (Fig. 3A). The net oxygen production in the Oyster mesocosms was negative from Day 5 onwards. The results were significantly different between the Oyster or Fish mesocosms and the Controls for the whole experiment.

The microbial community respiration rates varied between a mean of 10.96 in the Controls mesocosms on Day 1 and a mean of $23.48 \mathrm{\mu g} \mathrm{l}^{-1} \mathrm{~h}^{-1}$ in the Oyster mesocosms on Day 5 (Fig. 3B). There was a significant peak in respiration rates in the Fish mesocosms on Day 3 (mean $120.67 \mu \mathrm{g} \mathrm{l}^{-1} \mathrm{~h}^{-1}$ ). Overall, there were significant differences in microbial community respiration rates between the Oyster or Fish mesocosms and the Controls for the whole experiment.

The gross oxygen production (GPP) decreased from a mean of 148.84 to a mean of $22.22 \mu \mathrm{g} \mathrm{l}^{-1} \mathrm{~h}^{-1}$ in the Control mesocosms during the experiment (Fig. 3C). In the Oyster mesocosms, the gross oxygen production decreased significantly, and was close to 0 on Days 5 and 9 (Fig. 3C). GPP was significantly higher in the Fish mesocosms on Day 3 (mean $235.82 \mu \mathrm{g}$ $\mathrm{l}^{-1} \mathrm{~h}^{-1}$ ). There were significant differences between the Oyster or Fish mesocosms and the Controls for the whole experiment. The gross oxygen production was 20 to $180 \%$ higher in the Fish mesocosms and up to $100 \%$ lower in the Oyster mesocosms than in the Controls.

\section{MFW components and metazooplankton}

The mean abundance of VLPs for all mesocosms was $(7.4 \pm 1.1) \times 10^{7} \mathrm{ml}^{-1}$ at the beginning of the experiment (Fig. 4A). VLP abundance in the Oyster mesocosms was significantly lower than in the Controls, but there was no significant difference between the VLP in the Fish mesocosms and the Controls although abundances were generally higher in the

Fig. 2. Concentrations (means, with error bars showing range, $\mathrm{n}=2$ ) of (A) nitrates (nitrite and nitrate: $\mathrm{NO}_{2}{ }^{-}+\mathrm{NO}_{3}{ }^{-}$), (B) phosphate $\left(\mathrm{PO}_{4}{ }^{3-}\right),(\mathrm{C})$ silicate $\left(\mathrm{SiO}_{4}{ }^{4-}\right)$, and (D) dissolved organic carbon (DOC) for the Oyster, Fish, and Control mesocosms in the course of the experiment. Red asterisks: significant difference $(p \leq 0.05)$ between the Oyster and Control mesocosms for the whole experiment 

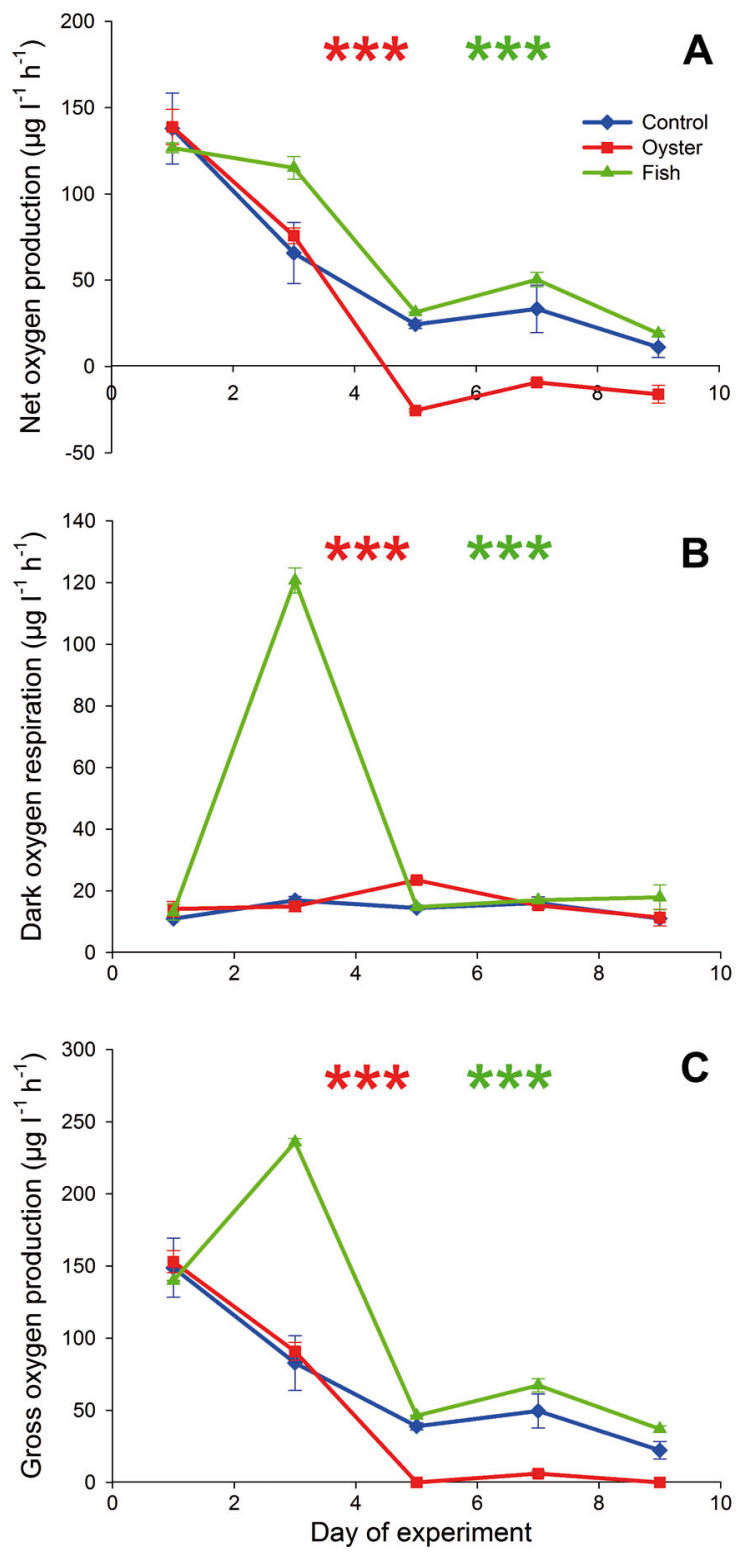

Fig. 3. Concentrations of (A) net oxygen community production (means, with error bars showing range, $n=2)$, (B) dark oxygen respiration of the microbial community measurement, and (C) gross oxygen production (means, with error bars showing range, $\mathrm{n}=2$ ) calculated from light/dark incubations, in the Oyster, Fish, and Control mesocosms during the experiment. Red and green asterisks: significant difference $(p \leq 0.05)$ between the Oyster or Fish mesocosms, respectively, and the Controls for the whole experiment

Controls. At the end of the experiment, VLP abundances had decreased from a mean of $7.3 \times 10^{7} \mathrm{ml}^{-1}$ in the Controls to a mean of $4.5 \times 10^{7} \mathrm{ml}^{-1}$ in the Fish mesocosms and a mean of $2.5 \times 10^{7} \mathrm{ml}^{-1}$ in the Oyster mesocosms.

The mean abundance of heterotrophic bacteria for all mesocosms was $(3.6 \pm 0.50) \times 10^{6} \mathrm{ml}^{-1}$ at the beginning of the experiment and, after increasing sharply up to Day 2 in all 6 mesocosms ([9.30 \pm 0.16$]$ $\times 10^{6} \mathrm{ml}^{-1}$ ), remained almost constant in the Oyster mesocosms, decreasing in a similar pattern in both the Fish mesocosms and the Controls before a slight increase on Day 8 (Fig. 4B). There was a significant difference between the bacterial abundances in the Oyster mesocosms and the Controls for the whole experiment (with significantly higher values in the Oyster mesocosms on Days 3, 6, and 7), but no significant difference between the Fish mesocosms and the Controls.

The total abundance of HFs $<10 \mu \mathrm{m}$ was about 597 $\pm 74 \mathrm{Cells} \mathrm{ml}^{-1}$ at the beginning of the experiment (Fig. 4C). After reaching a mean of $1610 \mathrm{ml}^{-1}$ on Day 1, abundances of HFs $<10 \mu \mathrm{m}$ in the Oyster mesocosms decreased significantly at a constant rate relative to the Controls until Day 9. In the Fish mesocosms, abundances of HFs $<10 \mu \mathrm{m}$ were relatively high at about $2000 \mathrm{ml}^{-1}$ during Days 3, 5, and 7 but were not significantly different from the abundances observed in the Controls (Fig. 4C). The Oyster mesocosms were significantly different from the Controls for the whole experiment, but the Fish mesocosms were not.

The total abundance of ciliates $<35 \mu \mathrm{m}$ increased constantly from the beginning of the experiment until Day 3 when the abundances were insignificantly lower in the Oyster (mean $3.46 \mathrm{ml}^{-1}$ ) and Fish (mean $2.89 \mathrm{ml}^{-1}$ ) mesocosms than in the Controls (mean $4.59 \mathrm{ml}^{-1}$; Fig. 4D). The abundances in the Oyster mesocosms remained almost constant on Days 5 and 7, whereas they decreased sharply in the other 4 mesocosms. There were no significant differences between the Oyster or Fish mesocosms and the Controls.

The most abundant metazooplankton groups at the beginning of the experiment were cyclopoid nauplii, calanoid nauplii, lamellibranch larvae, gastropod larvae, Oithona nana, and Synchaeta triophthalma. Fig. 5 illustrates the variations in abundance of these metazooplankton groups and species during the experiment in the 6 mesocosms. The abundance of cyclopoid nauplii in the Oyster treatment seemed to be higher than the Control mesocosms and Fish treatment at the beginning of the experiment (Day 1), although the range of the observations in the Control mesocosms was larger than that of the Oyster and Fish treatments. This difference could be related to the fact that the distribution of the large organisms in the mesocosms was not necessarily homogeneous despite the use of pumps to mix the mesocosms. The abundance of the metazooplankton groups and species in the Control mesocosms remained more or less 
stable or decreased slightly during the experiment. At the end of the experiment, the abundance of all of these metazooplankton was significantly lower in the Oyster mesocosms than in the Controls, but in the Fish mesocosms there was preferential predation on certain groups of metazooplankton (cyclopoid nauplii, gastropod larvae, and $O$. nana), with the general abundance remaining higher than in the Oyster mesocosms (Fig. 5A-F). There were significant differences in the abundances of cyclopoid nauplii, gastropod larvae, and lamellibranch larvae between the Oyster mesocosms and the Controls for the whole experiment, and there were significant differences in the abundances of gastropod and lamellibranch larvae between the Fish mesocosms and the Controls.

The mean chl a concentration for all mesocosms was $3.55 \pm 0.23 \mu \mathrm{g} \mathrm{l}^{-1}$ on Day 1 (Fig. 6). In the Controls, chl a concentrations decreased until Day 4 (mean $1.53 \mu \mathrm{g} \mathrm{l}^{-1}$ ) and after increasing (Days 5 and 7) and decreasing (Days 6 and 8), reached a mean of $1.62 \mu \mathrm{g} \mathrm{l}^{-1}$ at the end of the experiment. The chl a concentrations in the Fish mesocosms were not significantly different from the Controls for the whole experiment. The only significantly higher concentration of chl $a$ in the Fish mesocosms than in the Controls was on Day 4, after which it followed a similar pattern to the Controls but with higher concentrations. However, there was a significant difference in chl a concentrations between the Oyster mesocosms and the Controls for the whole experiment and significantly lower concentrations on Days 3, 5, 6, 7, 8, and 9. Chl a concentrations on Day 9 were $92.5 \%$ lower in the Oyster mesocosms and 50.8\% higher in the Fish mesocosms than in the Controls.

Table 1 summarizes the effects of oysters and fish as top predators on the organisms studied for the whole experiment.

\section{Microbial carbon biomass partitioning}

The total microbial C biomasses were 375, 337, and $373 \mu \mathrm{g} \mathrm{Cl}^{-1}$ at the beginning of the experiment (Day 1) in the Oyster, Fish, and Control mesocosms, and then decreased monotonically to 188,209 , and

Fig. 4. Abundances (means, with error bars showing range, $\mathrm{n}=2$ ) of (A) virus-like particles, (B) heterotrophic bacteria, (C) heterotrophic flagellates $<10 \mu \mathrm{m}$, and (D) ciliates $<35 \mu \mathrm{m}$ in the Oyster, Fish, and Control mesocosms during the experiment. Red asterisks: significant difference ( $p \leq 0.05)$ between the Oyster and Control mesocosms for the whole experiment
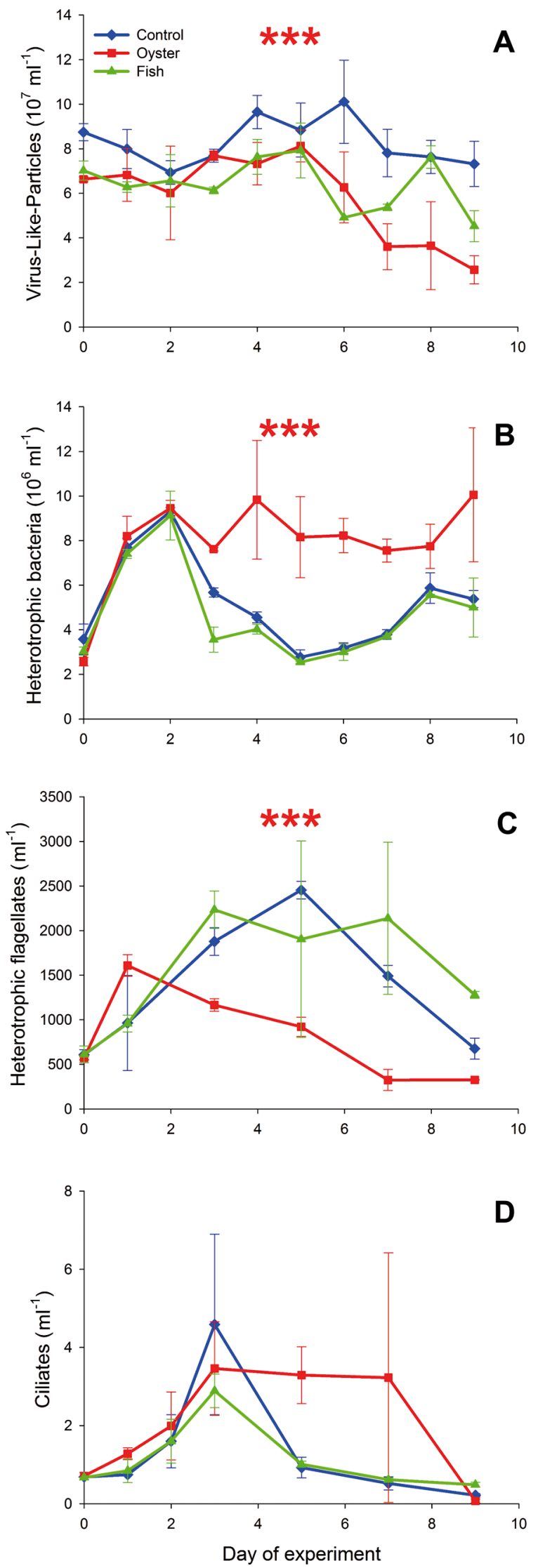

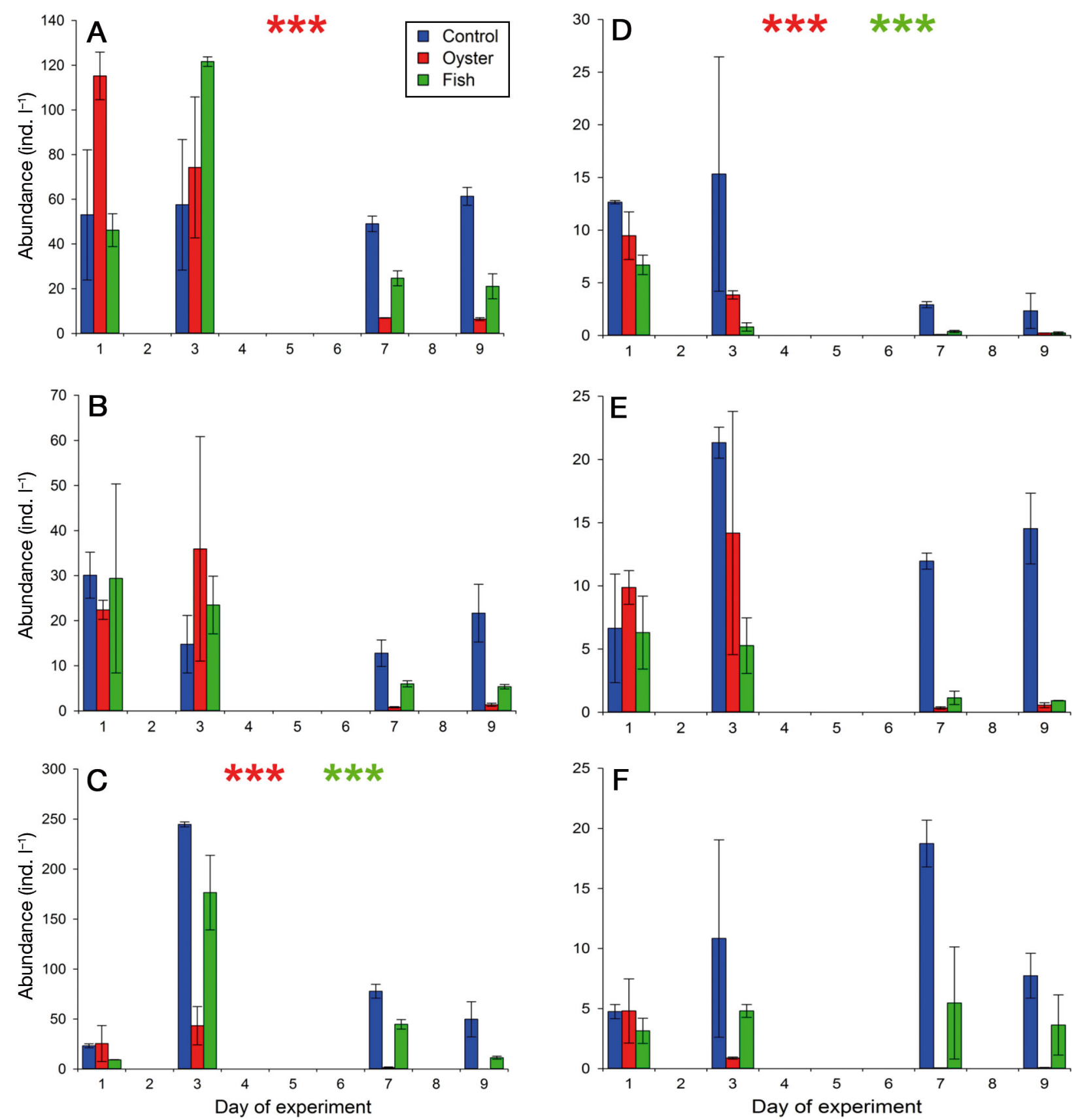

Fig. 5. Abundance (means, with error bars showing range, $\mathrm{n}=2$ ) of the 6 most abundant metazooplankton groups and species (ind. $\mathrm{l}^{-1}$ ) during the experiment in the Oyster, Fish, and Control mesocosms: (A) cyclopoid nauplii, (B) calanoid nauplii, (C) lamellibranch larvae, (D) gastropod larvae, (E) Oithona nana, and (F) Synchaeta triophthalma. Red and green asterisks: significant difference $(p \leq 0.05)$ between the Oyster or Fish mesocosms, respectively, and the Controls for the whole experiment

$184 \mu \mathrm{g} \mathrm{C} \mathrm{l}^{-1}$, respectively, on Day 5. On Day 7, the microbial C biomasses increased in the Fish $(261 \mu \mathrm{g}$

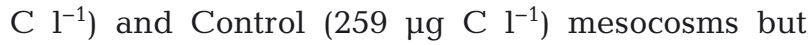
decreased in the Oyster mesocosms $\left(171 \mu \mathrm{g} \mathrm{C}^{-1}\right)$. At the end of the experiment (Day 9), the total microbial C biomass reached 210, 244, and $205 \mu \mathrm{g}$ $\mathrm{C}^{-1}$ in the Oyster, Fish, and Control mesocosms, respectively.
The major contributors to the microbial $\mathrm{C}$ biomasses were always the phytoplankton and heterotrophic bacteria (Fig. 7), which contributed more than $54 \%$ and $41 \%$, respectively, in all mesocosms on Day 1. The contribution of VLPs, HFs $<10 \mu \mathrm{m}$, and ciliates $<35 \mu \mathrm{m}$ to the total microbial $\mathrm{C}$ biomass never exceeded $5 \%$ during the experiment in any of the mesocosms. The phytoplankton $\mathrm{C}$ bio- 


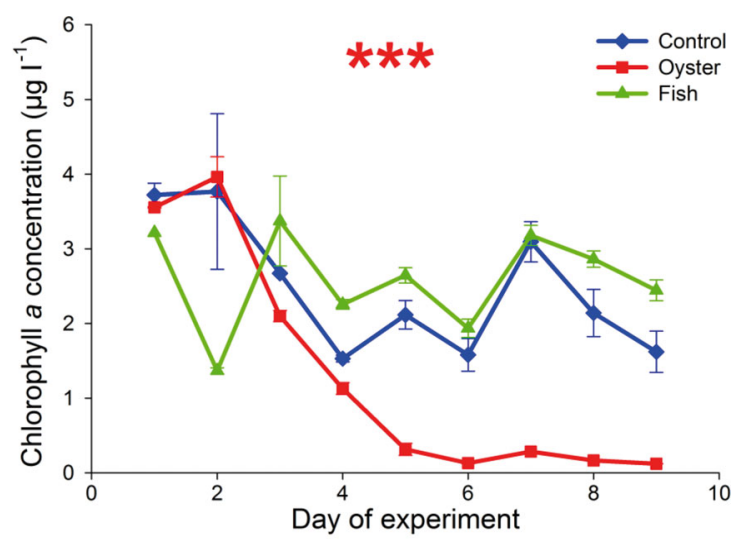

Fig. 6. Chlorophyll a concentrations (means, with error bars showing range, $\mathrm{n}=2$ ) measured by HPLC in the Oyster, Fish, and Control mesocosms during the experiment. Red asterisks: significant difference $(p \leq 0.05)$ between the

Oyster and Control mesocosms for the whole experiment
Table 1. Significant positive (+) and negative (-) effects of oysters and fish on microbial food web components and the most abundant metazooplankton. NS: not significant

\begin{tabular}{|llcc|}
\hline Trophic status & Organism & Oyster & Fish \\
\hline Heterotrophic & Virus & - & NS \\
Heterotrophic & Bacteria & + & NS \\
microorganisms & Flagellates $<10 \mu \mathrm{m}$ & - & NS \\
& Ciliates $<35 \mu \mathrm{m}$ & $\mathrm{NS}$ & $\mathrm{NS}$ \\
Autotrophic & Phytoplankton (chl a) & - & $\mathrm{NS}$ \\
microorganisms & & & \\
Heterotrophic & Cyclopoid nauplii & - & $\mathrm{NS}$ \\
metazooplankton & Calanoid nauplii & $\mathrm{NS}$ & $\mathrm{NS}$ \\
& Lamellibranch larvae & - & - \\
& Gastropod larvae & - & - \\
& Oithona nana & NS & NS \\
& Synchaeta triophthalma & NS & NS \\
\hline
\end{tabular}

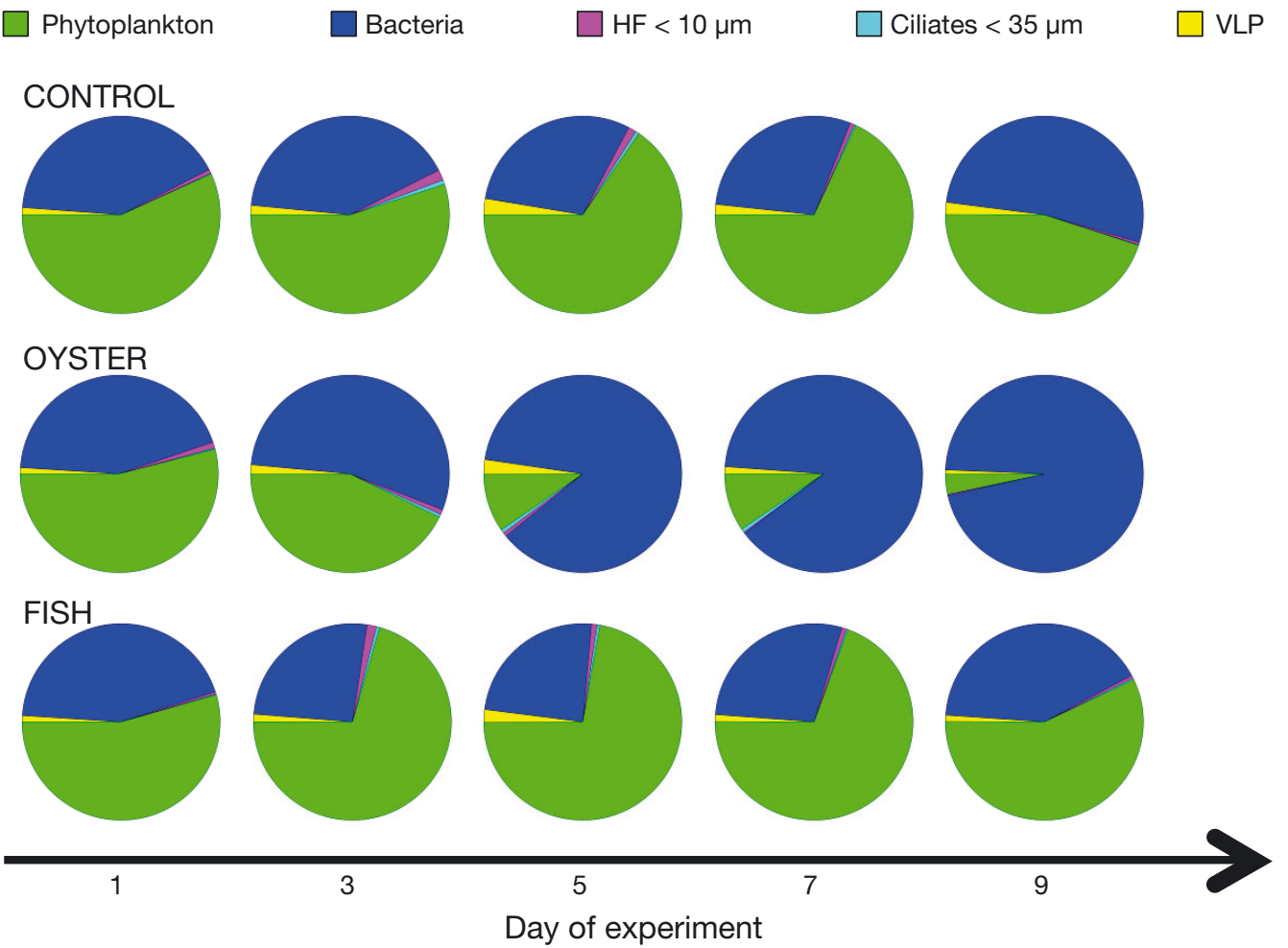

Fig. 7. Mean $(\mathrm{n}=2)$ of carbon partitioning of the microbial food web components in the Control, Oyster, and Fish mesocosms on Days 1, 3, 5, 7, and 9 of the experiment. Partitioning of phytoplankton is shown in green, heterotrophic bacteria in dark blue, heterotrophic flagellates $<10 \mu \mathrm{m}(\mathrm{HF})$ in pink, ciliates $<35 \mu \mathrm{m}$ in light blue, and virus-like particles (VLP) in yellow

mass on Day 5 was $85 \%$ lower in the Oyster mesocosms and $25 \%$ higher in the Fish mesocosms than in the Controls, and this difference was even more accentuated on Day 9 (93\% lower phytoplankton $\mathrm{C}$ biomass in the Oyster mesocosms and 51\% higher in the Fish mesocosms than in the Controls,
Fig. 7). The bacterial $\mathrm{C}$ biomasses in the Oyster mesocosms were $195 \%$ and $87 \%$ higher than in the Controls on Days 5 and 7 , in contrast to the Fish mesocosms, where they were $8 \%$ and $7 \%$ lower than in the Controls on Days 5 and 9 (Fig. 4B). 

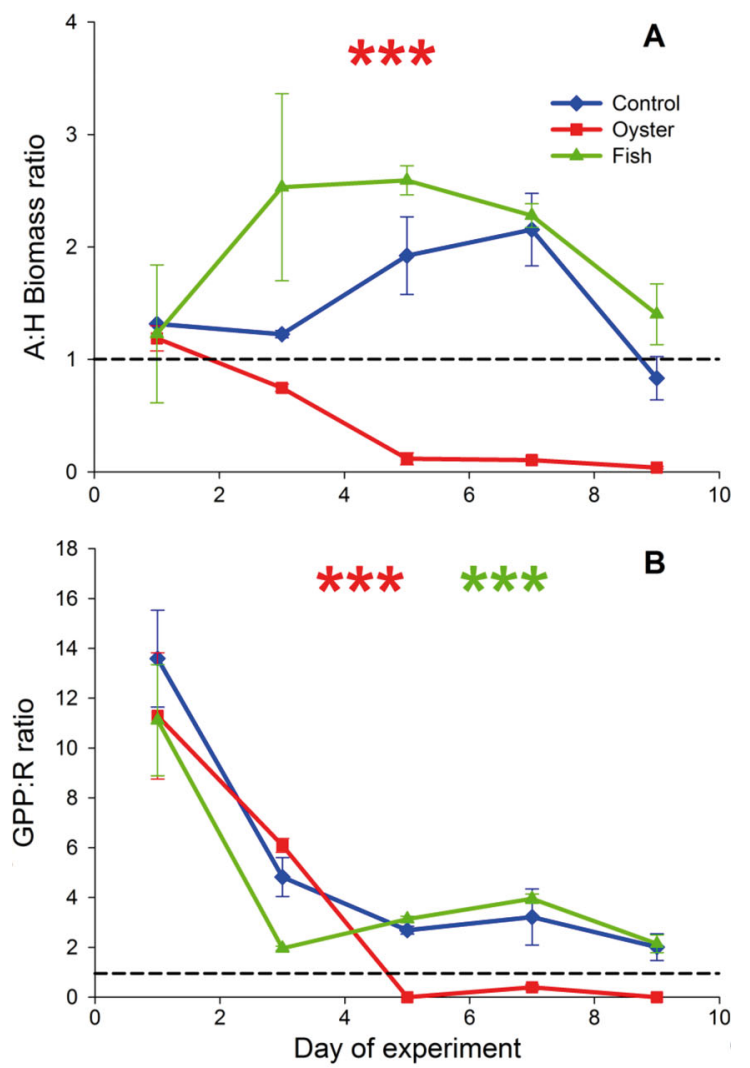

Fig. 8. Dynamics of microbial food web (A) structural index of autotroph:heterotroph (A:H) C biomass ratios and (B) functional index of gross primary production:respiration (GPP:R) ratios in the Oyster, Fish, and Control mesocosms during the experiment. Data are the means with error bars showing range $(n=2)$. The black dashed lines represent a ratio of 1 . Red and green asterisks: significant difference $(\mathrm{p} \leq 0.05)$ between the Oyster or Fish mesocosms, respectively, and the Controls for the whole experiment

\section{DISCUSSION}

In order to show the MFW structural and functional responses to oyster and fish top predators, the MFW autotroph:heterotroph $\mathrm{C}$ biomass ratios $(\mathrm{A}: \mathrm{H})$ were established as an MFW structural index. These were calculated considering the autotrophic $\mathrm{C}$ biomass to be the $\mathrm{C}$ biomass of chlorophyll and the heterotrophic $\mathrm{C}$ biomass to be the sum of the $\mathrm{C}$ biomasses of VLP, bacteria, HFs $<10 \mu \mathrm{m}$, and ciliates $<35 \mu \mathrm{m}$. The GPP:R was considered as an MFW functional index.

Fig. 8A shows the MFW structural A:H ratios in the 3 sets of mesocosms during the experiment, where a shift in the MFW A:H ratios from autotrophic $(\mathrm{A}: \mathrm{H}>1)$ to heterotrophic $(\mathrm{A}: \mathrm{H}<1)$ can be seen. Overall, the MFW was always autotrophic in the Fish and Control mesocosms, except for the last day of the experiment when it shifted towards heterotrophic in the Controls
(Fig. 8A). The A:H ratios were generally but not significantly higher in the Fish mesocosms $(>2)$ than in the Control mesocosms and were never heterotrophic. However, the Oyster mesocosms became heterotrophic after Day 1 until the end of the experiment, with ratios close to 0 (0.03 on Day 9 ). The A:H ratios in the Oyster mesocosms were significantly different from the Controls for the entire experiment, whereas the Fish mesocosms were not significantly different from the Controls.

Fig. 8B shows the variations in the MFW functional GPP:R ratio in the 3 sets of mesocosms during the experiment. The GPP:R ratio for all mesocosms decreased from Day 1 to Day 3 and then remained above 0 in the Fish and Control mesocosms until the end of the experiment, whereas it approached 0 in the Oyster mesocosms from Day 5 onwards. There were significant differences in the GPP:R ratios between the Oyster or Fish mesocosms and the Controls for the whole experiment. Note that the NCP provided the same information as GPP:R, with the same statistical significance for the whole experimental period; therefore, NCP can also be used as the functional index.

Studying the abundance and biomasses of the different MFW components to draw up an MFW structural index (A:H ratios) makes it possible to compare MFW components at different sites. Our results showed that the abiotic parameters of the experimental site at the beginning of the study were within the range of the normal autumn conditions before flood events (Fouilland et al. 2012). The phytoplankton community in the Thau lagoon is generally diatom dominated (Vaquer et al. 1996), although eukaryotic picoplankton (i.e. Ostreococcus tauri), cryptophytes, and dinoflagellates can also be important components seasonally or in particular conditions (Courties et al. 1994, Collos et al. 1997, Pecqueur et al. 2011). The phytoplankton community during the present experiment was dominated by diatoms and in particularly by colonies of Thalassionema nitzschioides (data not shown). The ciliate community in the Thau lagoon is dominated by Strombilidium spiralis, Mesodinium sp., Lhomaniella oviformis, and Uronema sp. (Pecqueur et al. 2011). The community of ciliates $<35 \mu \mathrm{m}$ in the present investigation was largely dominated by Strombidium sp., although other species like Mesodinium sp. Strombinopsis sp. and $S$. spiralis were also present during the experiment (data not shown).

The total microbial $\mathrm{C}$ biomass estimated at the beginning of the experiment (Day 1) was $373 \mu \mathrm{g} \mathrm{C} 1^{-1}$ in the Control mesocosms with $54 \%$ phytoplankton 
and $41 \%$ heterotrophic bacteria, with VLP, HFs $<10 \mu \mathrm{m}$, and ciliates $<35 \mu \mathrm{m}$ each accounting for around $1 \%$. The MFW structure (A:H ratio) at the beginning of our experiment was representative of MFW in the Thau lagoon in the fall, being autotrophic $(\mathrm{A}: \mathrm{H}=1.25)$, even though the nutrient concentrations were low at the time of the experiment. The published data for other study sites such as the Grand Entrée Lagoon (Magdalen Islands, Canada), where Mytilus edulis mussels are cultivated (Trottet et al. 2008), showed that heterotrophic organisms were dominant and that the A:H ratio was generally $<1$. In order to compare the MFW A:H ratio found for Thau lagoon at the beginning of the present study with ratios from other marine systems, we used the values of phyto-, bacterio-, and protozooplankton presented in the large data set in Table 1 from Gasol et al. (1997). The MFW A:H ratios (excluding metazooplankton C biomass) were then calculated for coastal and open ocean areas. This showed that the MFW A:H ratio in the fall at the Thau lagoon (1.25) was similar to the mean calculated for open ocean areas $(\mathrm{A}: \mathrm{H}=1.21)$ but much lower than the mean found for coastal areas $(\mathrm{A}: \mathrm{H}=3.42)$. This comparison highlights that in the fall, before the occurrence of any nutrient enrichment by flood events, the Thau lagoon had a lower autotrophic status than other coastal areas. It should be noted, however, that the A:H ratio of the Thau lagoon given here, like other ratios for coastal areas, may change in response to forcing factors. Consequently, monitoring the MFW components and the A:H structural index may help to show what changes are caused by global and local forcing factors, as will be discussed below, to identify which MFW components are most or least sensitive to forcing factors, and finally determine the degree of resilience of an MFW to these stresses and the time taken to return to the initial point before the perturbations.

This study set out to identify how oysters and fish affect the structure and functioning of the MFW. As top predators, oysters and fish exert top-down and bottom-up control on the MFW components. Our results showed both top-down and bottom-up controls in the Oyster and Fish mesocosms.

By removing large particles, the oyster Crassostrea gigas exerted a non-selective top-down control on organisms and directly decreased the biomass of the plankton community. This was particularly the case for chl a concentrations, which were significantly lower in the Oyster mesocosms than in the Controls from Day 3 onwards (Fig. 6). The decrease in chl a concentrations was due mainly to filtration of the larger phytoplankton such as diatoms (data not shown) which caused the dissolution of diatom frustule microstructures and a significant increase in silicate concentrations in the Oyster mesocosms compared to the Controls from Day 5 until the end of the experiment (Fig. 2C). This agrees with studies on the topdown effects of bivalves showing that chl a concentrations were strongly controlled by filter feeders (Cugier et al. 2010). Consequently, bivalve suspension feeders such as oysters have been proposed for ecological engineering to reduce phytoplankton biomass and restore productive environments (Fulford et al. 2007). However, there has been some debate on the capacity of oysters to control spring phytoplankton blooms (Pomeroy et al. 2006, 2007, Newell et al. 2007) which seems to depend on the natural conditions in different sites. In the Thau lagoon, Souchu et al. (2001) found that chl $a$ in the western part, where most of the shellfish farms were located, was almost $40 \%$ lower than outside the shellfish farming area. Ten years later at the same study site, after mass mortality of young oysters, only $19 \%$ lower chl a concentrations within the farming area than outside the farming area were found (Pernet et al. 2012), indicating an inverse relationship between oysters and phytoplankton biomass. Other studies, however, have shown, for example, that grazing of cultured pearl oysters decreases the particulate organic carbon but not the phytoplankton biomass (Charpy et al. 2012), concluding that pearl oysters graze mainly on non-chlorophyllian particles. Oysters may also consume heterotrophic bacteria, flagellates, and ciliates, as demonstrated by Dupuy et al. (2000).

Our results show that oysters not only significantly reduce phytoplankton biomass but also significantly reduce the abundances of VLP, HFs $<10 \mu \mathrm{m}$, cyclopoid nauplii, lamellibranch larvae, and gastropod larvae (Figs. 4A,C \& 5A,C,D, respectively). Other dominant metazooplankton were also filtered actively by the oysters and were less abundant in the Oyster mesocosms than in the Controls at the end of the experiment (Fig. 5). Some studies focusing on the key food sources for the growth of bivalves also showed that phytoplankton biomass alone cannot explain their growth and that heterotrophic organisms such as bacteria, flagellate and ciliate microzooplankton, and even aggregates contributed to the growth of the mussel Perna canaliculus (Safi \& Hayden 2010). Based on a study of the nitrogen budget in the Thau lagoon, Mazouni (2004) concluded that heterotrophic microorganisms can be a nitrogen source in the diet of oysters. Another experimental study showed that grazing by bivalves was probably among the major 
regulatory factors affecting zooplankton by removing ciliates and copepod eggs (Lonsdale et al. 2009).

In our study, heterotrophic bacteria were the only microorganism whose abundances were significantly higher in the Oyster mesocosms than in the Controls (Fig. 4B, Table 1), even though bacteria were part of the oyster diet. There are several explanations for the higher abundance of bacteria with filtration by oysters. Bacteria might benefit from the oyster excreta, although there were no significant changes in DOC concentrations in the mesocosms or any direct measurements of oyster excreta and bacterial assimilation during the experiment. However, it has been established that the excreta of suspended bivalves is a source of dissolved nitrogen (Mazouni et al. 1998), contributing significantly to nitrogen regeneration in the water column (Baudinet et al. 1990) and indicating that oysters exert bottom up control over MFW components.

Another explanation for the higher abundance of heterotrophic bacteria in the Oyster mesocosms than in the Controls may be related to interactions between bacteria and other organisms. Firstly, the VLP abundances were significantly lower in the Oyster mesocosms than in the Controls, especially at the end of the experiment (Fig. 4A). The role of viruses in the mortality of marine microorganisms is well known (Fuhrman 1999). Oysters may decrease viral abundances either by taking in viruses which are absorbed to particles such as phytoplankton, or by interrupting the virus life cycle by filtering out infected microorganisms. Retention of viruses by oysters was also reported by Schikorski et al. (2011), who showed, for example, that summer mortalities of C. gigas larvae and spat were associated with the presence of ostreid herpesvirus 1 (OsHV-1). Heterotrophic bacteria in the Oyster mesocosms where viruses were less abundant might have been less infected and, therefore, maintained their higher abundances in the Oyster mesocosms than in the Controls. Secondly, heterotrophic bacteria benefited from the significant reduction of $\mathrm{HFs}<10 \mu \mathrm{m}$ (Fig. 4C) which might have resulted in lower bacteriovory in the Oyster mesocosms than in the Controls. Lower concentrations of HFs $<10 \mu \mathrm{m}$ in the presence of the oysters could be due to direct oyster filtration of HFs $<10 \mu \mathrm{m}$, or to an indirect effect through a trophic cascade. In this second scenario, the oysters would have filtered the metazooplankton (Fig. 5), which in turn fed less on ciliates $<35 \mu \mathrm{m}$ resulting in higher ciliate abundances (Fig. 4D), which then increased grazing pressure on HFs $<10 \mu \mathrm{m}$. Finally, reducing phytoplankton competition with hetero- trophic bacteria for inorganic nutrient resources might have provided more available nutrients for bacteria, resulting in higher abundances in the Oyster mesocosms than in the Controls.

All of these structural changes caused by oysters are reflected in the MFW structural A:H index, which tended to give ratios below 1 (Fig. 8A), indicating a trend towards a more heterotrophic microbial system. This structural change in the MFW occurred in parallel with the MFW functional GPP:R index from Day 5 until the end of the experiment, with values close to 0 indicating that the respiration rates were much higher than the production rates (Fig. 8B).

This study also showed that the sand smelt Atherina spp. exerted top-down control preferentially on metazooplankton communities (Fig. 4), the abundances of all groups and species being lower at the end of the experiment than in the Controls. The selective removal of metazooplankton by Atherina increased the abundance of metazooplankton prey, in particular phytoplankton (Fig. 6). The chl a concentration was $51 \%$ higher in the Fish mesocosms than in the Controls on Day 9. The dynamics of other organisms during the experiment were more or less similar to those observed in the Controls. These results are in accordance with those of the literature indicating that fish can exert top-down control by predation or filtration, affecting plankton communities through trophic cascades. For example, Lacerot et al. (2013) demonstrated that fish strongly reduced the abundance of the largest zooplankton even with low fish densities during 2 outdoor mesocosm experiments in a subtropical, nutrient-rich lake. It should be noted, however, that the top-down effect of fish on the food web components depends on the fish feeding regime. For example, using paleolimnological records, Strock et al. (2013), showed that the introduction of white perch Morone americana, a fish switching from a strict planktivory to a more generalist diet during ontogeny, into an oligotrophic lake caused an increase in the size of cladoceran ephippia and reduced the algal standing crop.

As already stated, the excreta of marine animals can have a significant effect on MFW components. For example, Arzul et al. (2001) demonstrated that the growth rate of Chaetoceros gracilis was inhibited by the excreta of seabass but was simulated by the excreta of oysters. These authors studied several species and concluded that the organic components of dissolved excreta of finfish (seabass Dicentrarchus labrax and salmon Salmo salar) tended to be inhibitors for the phytoplankton species studied, whereas the organic components of dissolved excreta of shell- 
fish (oysters C. gigas and mussels Mytilus chilensis) tended to be stimulators. In our study, it was not possible to isolate any bottom-up effect of fish on the MFW components and, in any case, it is clear that the effects of animal excreta on the MFW components depend on the fish species and the phytoplankton or bacterial species and groups. The zooplanktivorous fish in this study produced an MFW structural index $\mathrm{A}: \mathrm{H}>1$, which was always greater than in the Control mesocosms (Fig. 8A), indicating an increase in autotrophic biomass. The fish also stimulated the community oxygen metabolism with a significant increase in GPP (Fig. 3B) and dark microbial respiration (Fig. 3C) at the beginning of the experiment. This led to a significantly greater GPP:R for the Fish mesocosms than the Controls for the whole experiment (Fig. 8B). It should be noted that according to the measurement of all oysters and fish biomass at the end of the experiment, the wet weight of 10 oysters (250 g, without valves) was 12 -fold greater than that of 29 fish (about $20 \mathrm{~g}$ ) in each of the Oyster and Fish mesocosms. Because oysters and fish have a drastically different alimentary regime (particle filtration and predation on zooplankton, respectively), MFW exposed to equivalent oyster and fish biomass are likely to respond in a similar way as observed in the present study, with differences between Oyster and Fish treatments probably even more pronounced.

The MFW structural (A:H ratio) index must be based on several samples and requires considerable time to analyze all of the MFW components. However, the MFW functional index (GPP:R, Fig. 8B), which agrees with the structural index $(\mathrm{A}: \mathrm{H})$, can be established by measurements of oxygen production and respiration. Recently, Mostajir et al. (2013) fitted several in situ mesocosms with a set of sensors for measuring water temperature, conductivity, chl a fluorescence, and dissolved oxygen concentration. These simultaneous automatic measurements are noninvasive and can be taken at high temporal resolution (every $2 \mathrm{~min}$ ) with data transmission in real time. This automatic monitoring is a powerful approach showing short-term variations in chl $a$ and MFW metabolism such as net and gross community production and community respiration (Mostajir et al. 2013), which can help to determine the trophic status of the system. These sets of sensors can be used not only in mesocosms but also in situ in coastal areas. Monitoring the MFW functional index GPP:R in situ can serve as an alert system. However, in the natural environment, there is advection of the water mass owing to wind and also water exchange, and so the water movements should be monitored by cur- rent meters (e.g. acoustic Doppler current profiler) to assess whether MFW components are being changed by water mass advection during the monitoring period.

Our results clearly show that oysters drive the MFW towards a more heterotrophic microbial loop, while fish (Atherina sp.) made the MFW more autotrophic. These results can be used for sustainable management of marine coastal environments by balancing the biomass of cultivated bivalves with that of local wild zooplanktivorous fish by improving their natural habitats in coastal areas. Oysters need phytoplankton which is also grazed by metazooplankton. By removing metazooplankton, local wild zooplanktivorous fish contribute to phytoplankton development which benefits oysters. In other words, maintaining the equilibrium between oysters and local wild zooplanktivores not only helps to maintain the MFW equilibrium in coastal areas but also improves the sustainable exploitation of cultivated resources. In addition, managing the equilibrium can increase the resilience of the system by decreasing the risk of environmental incidents caused by the system becoming too heterotrophic.

As already stated, marine coastal environments are subject to many global and local forcing factors which may combine with unexpected results. The results presented here show that bivalves do make the MFW more heterotrophic, a shift that could become even more pronounced in the eutrophic coastal zone with global warming. This is based on the arguments put forward by O'Connor et al. (2009) suggesting that in nutrient-poor regions, the food web may be more resilient to warming because consumer production is primarily limited by resource availability, whereas in eutrophic regions temperature may be the primary driver, and small amounts of warming may have dramatic effects on the trophic structure, primary productivity, and standing biomass.

\section{CONCLUSIONS}

Studying and monitoring all MFW components made it possible to (1) determine the relative importance of MFW components and (2) establish structural (A:H) and functional (GPP:R) MFW indices which can be used to assess the impact of local and global forcing factors on the MFW. As a local biological forcing factor, cultivated filter feeders increased the number of smaller organisms, in particular bacteria, by removing larger particles and made the MFW more heterotrophic (both A:H and GPP:R $<1$ ), creat- 
ing a less productive microbial loop. On the other hand, zooplanktivorous fish, by predating preferentially on zooplankton, benefited the prey of zooplankton, in particular phytoplankton, and therefore made the MFW more autotrophic (both MFW indices $>1$ ). The equilibrium between the biomass of cultivated filter feeders and that of local wild zooplanktivorous fish (or other zooplanktivores for polyculture farming) may help to make the MFW more autotrophic and more productive. This may also create a more resilient system for sustainable cultivated bivalve production especially with climate change.

Acknowledgements. We are grateful to C. Rougier and T. Lam-Hoai for zooplankton analysis, L. Oriol for nutrient analysis, B. Charrière for DOC analysis, F. Cantet, C. Leboulanger, M. M'Boup, and Y. Vergne for their assistance during the experiment, $\mathrm{M}$. Cantou for collecting the oysters and J.A. Tomasini for catching the fish, and T. Do Chi for advice on the type of fish to be used in this experiment. This study is part of the Oyster \& Fish project 'Effects of oyster and fish on pelagic microbial food web' supported by the French National PNEC Program ('Programme National en Environnement Côtier'). B.M. received funding and coordinated the project. MEDIMEER infrastructures were funded by UMR 5119 ECOSYM, National Center of Scientific Research (CNRS-Environment and Sustainable Development Department), IFR 129 Armand Sabatier, CNRS-GDR 2476 Aquatic Food Webs, and the Languedoc Roussillon Region.

\section{LITERATURE CITED}

Arzul G, Seguel M, Clément A (2001) Effect of marine animal excretions on differential growth of phytoplankton species. ICES J Mar Sci 58:386-390

Baudinet D, Alliote E, Berland B, Grenz C and others (1990) Incident of mussel culture on biogeochemical fluxes at the sediment-water interface. Hydrobiologia 207: 187-196

Booth BC (1993) Estimating cell concentration and biomass of autotrophic plankton using microscopy. In: Kemp PF, Sherr BF, Sherr EB, Cole JJ (eds) Handbook of methods in aquatic microbial ecology. CRC Press, Boca Raton, FL, p 199-205

Caritt D, Carpenter J (1966) Comparison and evaluation of currently employed modifications of the Winkler method for determining dissolved oxygen in sea-water; a NASCO report. J Mar Res 24:286-318

> Carpenter SR, Kitchell JF, Hodgson JR, Cochran PA and others (1987) Regulation of lake primary productivity by food web structure. Ecology 68:1863-1876

Charpy L, Rodier M, Fournier J, Langlade MJ, GaertnerMazouni N (2012) Physical and chemical control of the phytoplankton of Ahe lagoon, French Polynesia. Mar Pollut Bull 65:471-477

Collos Y, Vaquer A, Bibent B, Slawyk G, Garcia N, Souchu P (1997) Variability in nitrate uptake kinetics of phytoplankton communities in a Mediterranean coastal lagoon. Estuar Coast Shelf Sci 44:369-375
Courties C, Vaquer A, Chretiennot-Dinet MJ, Troussellier M and others (1994) Smallest eukaryotic organism. Nature 370:255

- Cugier P, Struski C, Blanchard M, Mazurie J and others (2010) Assessing the role of benthic filter feeders on phytoplankton production in a shellfish farming site: Mont Saint Michel Bay, France. J Mar Syst 82:21-34

> Dupuy C, Vaquer A, Lam-Höai T, Rougier C and others (2000) Feeding rate of the oyster Crassostrea gigas in a natural planktonic community of the Mediterranean Thau Lagoon. Mar Ecol Prog Ser 205:171-184

Field CB, Behrenfeld MJ, Randerson JT, Falkowski P (1998) Primary production of the biosphere: integrating terrestrial and oceanic components. Science 281:237-240

$>$ Fouilland E, Trottet A, Bancon-Montigny C, Bouvy M and others (2012) Impact of a river flash flood on microbial carbon and nitrogen production in a Mediterranean Lagoon (Thau Lagoon, France). Estuar Coast Shelf Sci 113:192-204

> Fouilland E, Mostajir B, Torréton JP, Bouvy M and others (2013) Microbial carbon and nitrogen production under experimental conditions combining warming with increased ultraviolet-B radiation in Mediterranean coastal waters. J Exp Mar Biol Ecol 439:47-53

> Fuhrman JA (1999) Marine viruses and their biogeochemical and ecological effects. Nature 399:541-548

Fulford RS, Breitburg DL, Newell RIE, Kemp WM, Luckenbach M (2007) Effects of oyster population restoration strategies on phytoplankton biomass in Chesapeake Bay: a flexible modeling approach. Mar Ecol Prog Ser 336: 43-61

> Gasol JM, del Giorgio AP, Duarte CM (1997) Biomass distribution in marine communities. Limnol Oceanogr 42: 1353-1363

Lacerot G, Kruk C, Lürling M, Scheffer M (2013) The role of subtropical zooplankton as grazers of phytoplankton under different predation levels. Freshw Biol 58:494-503

Lam-Hoai T (1991) Zooplankton counted by image analysis and size-frequency distributions in a coastal lagoon. Arch Hydrobiol 121:147-159

> Lam-Hoai T, Rougier C, Lasserre G (1997) Tintinnids and rotifers in a northern Mediterranean coastal lagoon. Structural diversity and function through biomass estimations. Mar Ecol Prog Ser 152:13-25

> Lam-Hoai T, Guiral D, Rougier C (2006) Seasonal change of community structure and size spectra of zooplankton in the Kaw River estuary (French Guiana). Estuar Coast Shelf Sci 68:47-61

Latasa M, Moran X, Scharek R, Estrada M (2005) Estimating the carbon flux through main phytoplankton groups in the northwestern Mediterranean. Limnol Oceanogr 50: 1447-1458

> Lonsdale DJ, Cerrato RM, Holland R, Mass A and others (2009) Influence of suspension-feeding bivalves on the pelagic food webs of shallow, coastal embayments. Aquat Biol 6:263-279

> Marie D, Partensky F, Jacquet S, Vaulot D (1997) Enumeration and cell cycle analysis of natural populations of marine picoplankton by flow cytometry using the nucleic acid stain SYBR green I. Appl Environ Microbiol 63: 186-193

Mazouni N (2004) Influence of suspended oyster cultures on nitrogen regeneration in a coastal lagoon (Thau, France). Mar Ecol Prog Ser 276:103-113

> Mazouni N, Gaertner JC, Deslous-Paoli JM (1998) Influence 
of oyster culture on water column characteristics in a coastal lagoon (Thau, France). Hydrobiologia 373/374: 149-156

Mostajir B, Demers S, de Mora S, Belzile C and others (1999) Experimental test of the effect of ultraviolet- $B$ radiation in a planktonic community. Limnol Oceanogr 44:586-596

Mostajir B, Nouguier J, Le Floc'h E, Mas S, Pete R, Parin D, Vidussi $F$ (2012) Use of sensors in marine mesocosm experiments to study the effect of environmental changes on planktonic food webs. In: Le Galliard JF, Guarini JM, Gaill F (eds) Sensors for ecology. Toward integrated knowledge of ecosystems. Publication CNRS, Paris, p 305-329

Mostajir B, Le Floc'h E, Mas S, Pete R and others (2013) A new transportable floating mesocosm platform with autonomous sensors for real-time data acquisition and transmission for studying the pelagic food web functioning. Limnol Oceanogr Methods 11:394-409

Mostajir B, Amblard C, Buffan-Dubau E, de Wit R, Lensi R, Sime-Ngando $T$ (2015) Microbial food webs in aquatic and terrestrial ecosystems. In: Bertrand JC, Caumette P, Lebaron P, Normand P, Sime-Ngando T (eds) Environmental microbiology: fundamentals and applications. Springer, Netherlands, p 458-509

Newell RIE, Kemp WM, Hagy JD III, Cerco CF, Testa JM, Boynton WR (2007) Top-down control of phytoplankton by oysters in Chesapeake Bay, USA: comment on Pomeroy et al. (2006). Mar Ecol Prog Ser 341:293-298

Noble RT, Fuhrman JA (1998) Use of SYBR Green I for rapid epifluorescence counts of marine viruses and bacteria. Aquat Microb Ecol 14:113-118

> Nouguier J, Mostajir B, Le Floc'h E, Vidussi F (2007) An automatically operated system for simulating global change temperature and ultraviolet $B$ radiation increases: application to the study of aquatic ecosystem responses in mesocosm experiments. Limnol Oceanogr Methods 5:269-279

O'Connor MI, Piehler MF, Leech DM, Anton A, Bruno JF (2009) Warming and resource availability shift food web structure and metabolism. PLoS Biol 7:e1000178

> Pecqueur D, Vidussi F, Fouilland E, Le Floc'h E and others (2011) Dynamics of microbial planktonic food web components during a river flash flood in a Mediterranean coastal lagoon. Hydrobiologia 673:13-27

Pernet F, Barret J, Le Gall P, Corporeau C and others (2012) Mass mortalities of Pacific oysters Crassostrea gigas reflect infectious diseases and vary with farming practices in the Mediterranean Thau lagoon, France. Aquacult Environ Interact 2:215-237

Pomeroy LR, D'Elia CF, Schaffner LC (2006) Limits to topdown control of phytoplankton by oysters in Chesapeake Bay. Mar Ecol Prog Ser 325:301-309

Pomeroy LR, D'Elia CF, Schaffner LC (2007) Top-down control of phytoplankton by oysters in Chesapeake Bay, USA: reply to Newell et al. (2007). Mar Ecol Prog Ser 341: 299-301

Putt M, Stoecker D (1989) An experimentally determined carbon-volume ratio for marine oligotrichous ciliates from estuarine and coastal water. Limnol Oceanogr 34: 1097-1103

> Riebesell U, Gattuso JP, Thingstad TF, Middelburg JJ (2013) Arctic ocean acidification: pelagic ecosystem and biogeochemical responses during a mesocosm study. Biogeosciences 10:5619-5626
Safi KA, Hayden B (2010) Differential grazing on natural planktonic populations by the mussel Perna canaliculus. Aquat Biol 11:113-125

Schikorski D, Faury N, Pepin JF, Saulnier D, Tourbiez D, Renault T (2011) Experimental ostreid herpesvirus 1 infection of the Pacific oyster Crassostrea gigas: kinetics of virus DNA detection by q-PCR in seawater and in oyster samples. Virus Res 155:28-34

Sime-Ngando T, Gosselin M, Roy S, Chanut JP (1995) Significance of planktonic ciliated protozoa in the lower St. Lawrence Estuary: comparison with bacterial, phytoplankton, and particulate organic carbon. Aquat Microb Ecol 9:243-258

Sohrin R, Sempéré R (2005) Seasonal variation in total organic carbon in the northeast Atlantic in 2000-2001. J Geophys Res 110:C10S90

> Souchu P, Gasc A, Collos Y, Vaquer A, Tournier H, Bibent B, Deslous-Paoli JM (1998) Biogeochemical aspects of bottom anoxia in a Mediterranean lagoon (Thau, France). Mar Ecol Prog Ser 164:135-146

Souchu P, Vaquer A, Collos Y, Landrein S, Deslous-Paoli JM, Bibent B (2001) Influence of shellfish farming activities on the biogeochemical composition of the water column in Thau lagoon. Mar Ecol Prog Ser 218: 141-152

Steward GF, Fandino LB, Hollibaugh JT, Whitledge TE, Azam F (2007) Microbial biomass and viral infections of heterotrophic prokaryotes in the sub-surface layer of the central Arctic Ocean. Deep-Sea Res I 54:1744-1757

Strock KE, Saros JE, Simon KS, McGowan S, Kinnison MT (2013) Cascading effects of generalist fish introduction in oligotrophic lakes. Hydrobiologia 711:99-113

Tréguer P, Le Corre P (1975) Manuel d'analyse des sels nutritifs dans l'eau de mer: utilisation de l'Autoanalyzer II Technicon [Textbook of nutrient analysis in marine water: utilization of the Technicon Autoanalyzer II], $2^{\text {nd }}$ edn. Laboratoire d'Oceanographie chimique, Université de Bretagne Occidentale, Brest

Trottet A, Roy S, Tamigneaux E, Lovejoy C, Tremblay R (2008) Impact of suspended mussels (Mytilus edulis L.) on plankton communities in a Magdalen Islands lagoon (Quebec, Canada): a mesocosm approach. J Exp Mar Biol Ecol 365:103-115

Vaquer A, Troussellier M, Courtis C, Bibent B (1996) Standing stock and dynamics of picophytoplankton in the Thau Lagoon (northwest Mediterranean coast). Limnol Oceanogr 1821-1828

> Vidussi F, Mostajir B, Fouilland E, Le Floc'h E and others (2011) Effects of experimental warming and increased ultraviolet $\mathrm{B}$ radiation on the Mediterranean plankton food web. Limnol Oceanogr 56:206-218

> von Scheibner M, Dörge P, Biermann A, Sommer U, Hoppe HG, Jürgens K (2014) Impact of warming on phyto-bacterioplankton coupling and bacterial community composition in experimental mesocosms. Environ Microbiol 16: 718-733

Wood ED, Armstrong FA, Richards FA (1967) Determination of nitrate in sea water by cadmium copper reduction to nitrite. J Mar Biol Assoc UK 47:23-31

- Zapata M, Rodriguez F, Garrido JL (2000) Separation of chlorophylls and carotenoids from marine phytoplankton: a new HPLC method using a reversed phase $\mathrm{C}_{8}$ column and pyridine-containing mobile phases. Mar Ecol Prog Ser 195:29-45

Submitted: February 10, 2015; Accepted: July 17, 2015

Proofs received from author(s): September 3, 2015 